\title{
Predators of the Invasive Mussel Musculista senbousia (Mollusca: Mytilidae) ${ }^{1}$
}

\author{
Feffrey $A$. Crooks $^{2}$
}

\begin{abstract}
Musculista senhousia (Benson in Cantor, 1842) is a soft sedimentdwelling mussel that has spread anthropogenically from its native Asia to North America, Australasia, and Europe. This byssal mat-forming species can become overwhelmingly dominant and have dramatic impacts within invaded ecosystems, but its invasion may meet "ecological resistance" from native predators. In Mission Bay, San Diego, California, three fish species and two shorebirds were found to prey upon the mussel. Experimental results suggest that predation can dramatically impact intertidal mussel populations and may account for observed seasonal declines in the species. Despite the creation of a byssal cocoon, which may afford the mussel some protection, several taxa worldwide have been found to be Musculista predators. In addition, in areas where the mussel is native, humans impact mussel populations by gathering it for animal feed or bait, or to remove it from commercial shellfisheries grounds.
\end{abstract}

NonNative species are increasing in abundance throughout the world, and biological invasions now represent one of the most serious threats to the integrity of ecosystems (Vitousek et al. 1997, Mooney and Hobbs 2000). Exotic species can have a wide range of ecological interactions within invaded ecosystems, including competition with natives, alteration of the physical nature of habitats, or predation upon resident biota (Crooks and Khim 1999, Parker et al. 1999, Ruiz et al. 1999). Exotics also can be eaten by natives, which can provide food resources for resident biota as well as potentially limit the abun-

\footnotetext{
1 Portions of this work were funded by a grant from the National Sea Grant College Program, National Oceanic and Atmospheric Administration, under grant no. NA66RG0477, project no. R/CZ-150 through the California Sea Grant College System. The views herein are those of the author and do not necessarily reflect the views of NOAA or any of its subagencies. The U.S. Government is authorized to reproduce this paper for governmental purposes. Manuscript accepted 26 February 2001.

2 Smithsonian Environmental Research Center and Romberg Tiburon Center, 3152 Paradise Drive, Tiburon, California 94920-0855 (phone: 415-338-3531, fax: 978428-2661, E-mail: crooks@serc.si.edu).
}

Pacific Science (2002), vol. 56, no. 1:49-56 (C) 2002 by University of Hawai'i Press. All rights reserved dance of the invader. This control of exotics by the feeding activities of natives represents a potentially important form of "ecological resistance" to invasions, whereby the extent and impact of invaders can be limited (Elton 1958, Reusch 1998).

In the coastal embayments of San Diego, California, including San Diego Bay and Mission Bay, an abundant and conspicuous invader is the Japanese mussel, Musculista senbousia (Benson in Cantor, 1842). This mussel has successfully taken advantage of various synanthropic means of invasion in its spread around the world, including transport in ballast water, association with intentionally introduced oysters, and Lessepsian migration through the Suez Canal (Barash and Danin 1971, 1972, Carlton 1979, Crooks 1992). In addition to its native Asia, $M$. senbousia is now found in North America, Europe, Australia, and New Zealand (Carlton 1979, Willan 1987, Hoenselaar and Hoenselaar 1989). Musculista senhousia is a typical opportunistic species. It is small, with a maximum length of $3.5 \mathrm{~cm}$, is short-lived, with a maximum longevity of approximately $2 \mathrm{yr}$, and has fast growth (Morton 1974, Tanaka and Kikuchi 1978, Crooks 1996). Musculista senhousia can achieve considerable densities in both intertidal and subtidal soft sediments (Kikuchi and Péres 1977, Crooks 1992). Typical abundances are 
$5,000-10,000 \mathrm{~m}^{-2}$, but densities in excess of $150,000 \mathrm{~m}^{-2}$ have been reported in Mission Bay (Reusch and Williams 1998, Crooks and Soulé 1999, Dexter and Crooks 2000). Like other mytilid mussels, $M$. senhousia produces byssal threads. In its typical sandy or muddy habitat, the byssus is used to form a cocoon, which may protect the thin-shelled bivalve and stabilize the animal in the sediment (Morton 1974).

When the mussel occurs in high densities, individual cocoons can intertwine, forming a mat or carpet that contains shells, sediment, algae, and detritus (Morton 1974, Creese et al. 1997, Crooks 1998). These mats serve as biogenic habitat for a variety of small macrofauna, whose abundances within this structurally complex area are higher than in sediments without mats (Crooks 1998, Crooks and Khim 1999). Larger organisms such as surface-dwelling, suspension-feeding bivalves and eelgrass, however, can be inhibited by dense mats of mussels (Creese et al. 1997, Reusch and Williams 1998, Crooks 2001). In the intertidal habitats of Mission Bay, the mussel is typically seasonal, with highest abundances in the summer and fall (Crooks 1998).

Because of the important role of $M$. senbousia as a competitor and habitat modifier, it is of interest to identify potential mussel predators. There have been some studies to identify predators of exotics in marine systems (e.g., Carlton 1979, Carlton et al. 1990), but relatively few studies have employed experimental approaches (Reusch 1998). Thus, the goals of this research were to (1) use descriptive studies to evaluate potential $M$. senbousia predators in Mission Bay, San Diego, (2) experimentally test the ability of predators to limit the success of intertidal populations of the mussel, and (3) review available information on $M$. senhousia predators within native and invaded ecosystems.

\section{MATERIALS AND METHODS}

\section{Fish Gut Analysis}

To assess potential fish predators of mussels, stomach contents of five species were exam- ined. This study focused on an abundant benthic-feeding fish in Mission Bay, the yellowfin croaker, Umbrina roncador Jordan \& Gilbert, 1882, a drum (Sciaenidae). Additional fish examined were the spotfin croaker, Roncador stearnsii (Steindachner, 1875) (Sciaenidae); the sargo, Anisotremus davidsonii (Steindachner, 1875) (Haemulidae); the California halibut, Paralichtbys californicus (Ayres, 1859) (Bothidae); and the striped mullet, Mugil cepbalus Linnaeus, 1758 (Mugilidae). Fish were caught in gill nets from the subtidal of Mission Bay as part of research at HubbsSea World Research Institute (M. Shane, pers. comm.). Fish guts were examined for the presence of mussel shells in May 1991, September 1991, and January 1992. On each sampling date, M. senhousia shells were noted as being absent, present (i.e., some shells found), or abundant (i.e., shells represented the bulk of material) in the gut of each fish. Also, fish standard lengths were recorded.

\section{Shorebird Feeding Observations}

To assess feeding behavior of shorebirds on mussels, bird observations were made on 23 dates from January to March 1996. Census information (S. Maresch, pers. comm.) indicated that the two most common birds on the tidal flat were the willet, Catoptrophorus semipalmatus (Gmelin, 1789) (Scolopacidae), with an average of over 100 birds per census date, and the marbled godwit, Limosa fedoa (Linnaeus, 1758) (Scolopacidae), with an average of approximately 30 birds per date. These species were chosen for further observation of direct feeding upon mussels. To assess the numbers of mussels eaten, individual birds were observed with binoculars for approximately $4 \mathrm{~min}$, and the number of mussels consumed was recorded. Both bird species were observed to lift their beak off the mud surface to swallow or manipulate the mussels, which allowed the number eaten to be estimated. Also, mussels often were directly observed in the beaks before consumption.

\section{Predation Experiment}

To assess the effects of predation on mussel survivorship, a short-term experiment was 
conducted on the sandy-mud tidal flat in the Northern Wildlife Preserve in Mission Bay (see also Crooks 1996, 1998). In the experiment, the experimental units were circular sections of intact mats (diameter $=23 \mathrm{~cm}$ ) removed from dense mussel beds in eastern Mission Bay. Average mussel densities $( \pm 1$ $\mathrm{SE})$ in the mats were $5227( \pm 742)$ individuals $\mathrm{m}^{-2}$. Mats were transplanted onto the tidal flat, approximately $0.5 \mathrm{~m}$ above mean lower low water. At the time of the experiment, the tidal flat contained no mussel mats, although they had occurred there previously. The experiment was arranged as a randomized complete block, with six blocks of two mats each. One of the mats in each block randomly received a sideless mesh cage (mesh size $=2.5$ $\mathrm{cm}$ ), such as that used in previous experiments (Crooks 1998, Crooks and Khim 1999). This cage design minimizes flow effects while preventing large predators from reaching mussel mats. At the conclusion of the experiment, which ran from 22 November to 9 December 1996 , cores (diameter $=5.8 \mathrm{~cm}$ ) were taken from each plot. Sediment was sieved through a 1-mm mesh, and all mussels retained were counted and measured. Mussel biomass was estimated using the length/weight regressions provided in Crooks (1996). Statistical differences in abundances and biomass were assessed using paired $t$-tests.

\section{RESULTS}

Examination of fish guts revealed that three of the five species appeared to be feeding upon $M$. senbousia (Table 1). The yellowfin croaker ( $U$. roncador), spotfin croaker ( $R$. stearnsii), and sargo (A. davidonsii) all were found with mussel shells in the gut. Across all dates, $63 \%$ of yellowfin croaker, $100 \%$ of spotfin croaker, and $63 \%$ of sargo contained $M$. senhousia shells. In some cases, crushed mussel shells and sediment composed almost the entirety of gut contents. The two halibut ( $P$. californicus), a predator, and the three mullet (Mugil cephalus), an herbivore, contained no mussel shells.

Shorebirds also were found to be $M$. senbousia predators. In general, most shorebirds on the tidal flat followed the flooding or ebbing tide and fed at the water's edge. Both willets and marbled godwits appeared to feed heavily upon $M$. senhousia. These birds tended to pick up and vigorously shake large clumps of mud and mussel mats, then consume the mussels whole. Across all dates, the average numbers of $M$. senhousia eaten per minute $( \pm 1$ SE $)$ were $5.7 \pm 0.4$ for godwits and $4.6 \pm 0.3$ for willets. In addition to observing feeding behavior, $M$. senhousia predation by shorebirds was indicated by the presence of shells in bird regurgitate and feces found on the tidal flat.

In the experiment, transplanted mussel mats were greatly affected by predators (Figure 1). Mats in the caged plots appeared completely intact, but those in the uncaged plots were virtually absent. Final densities in the caged plots were over 35 times greater than those in the uncaged plots, and total biomass in the caged plots was over 75 times greater than that in uncaged plots. The primary predators in these experiments were

\section{TABLE 1}

Presence of Musculista senbousia in Guts of Fish Collected from Mission Bay, San Diego, California, with Standard Lengths (SL) and Numbers of Fish Examined

\begin{tabular}{llcrrr}
\hline \hline & & & & \multicolumn{2}{c}{ No. of fish with: } \\
\cline { 5 - 6 } Fish Species & Common Name & SL $(\mathrm{cm})$ & No Shells & Few Shells & Many Shells \\
\hline Umbrina roncador $(n=27)$ & Yellowfin croaker & $17-33$ & 10 & 10 & 7 \\
Roncador stearnsii $(n=5)$ & Spotfin croaker & $34-47$ & 0 & 1 & 4 \\
Anisotremus davidsonii $(n=8)$ & Sargo & $19-21$ & 3 & 3 & 2 \\
Paralichthys californicus $(n=2)$ & Halibut & $15-20$ & 2 & 0 & 0 \\
Mugil cephalus $(n=3)$ & Mullet & $31-38$ & 3 & 0 & 0 \\
\hline
\end{tabular}



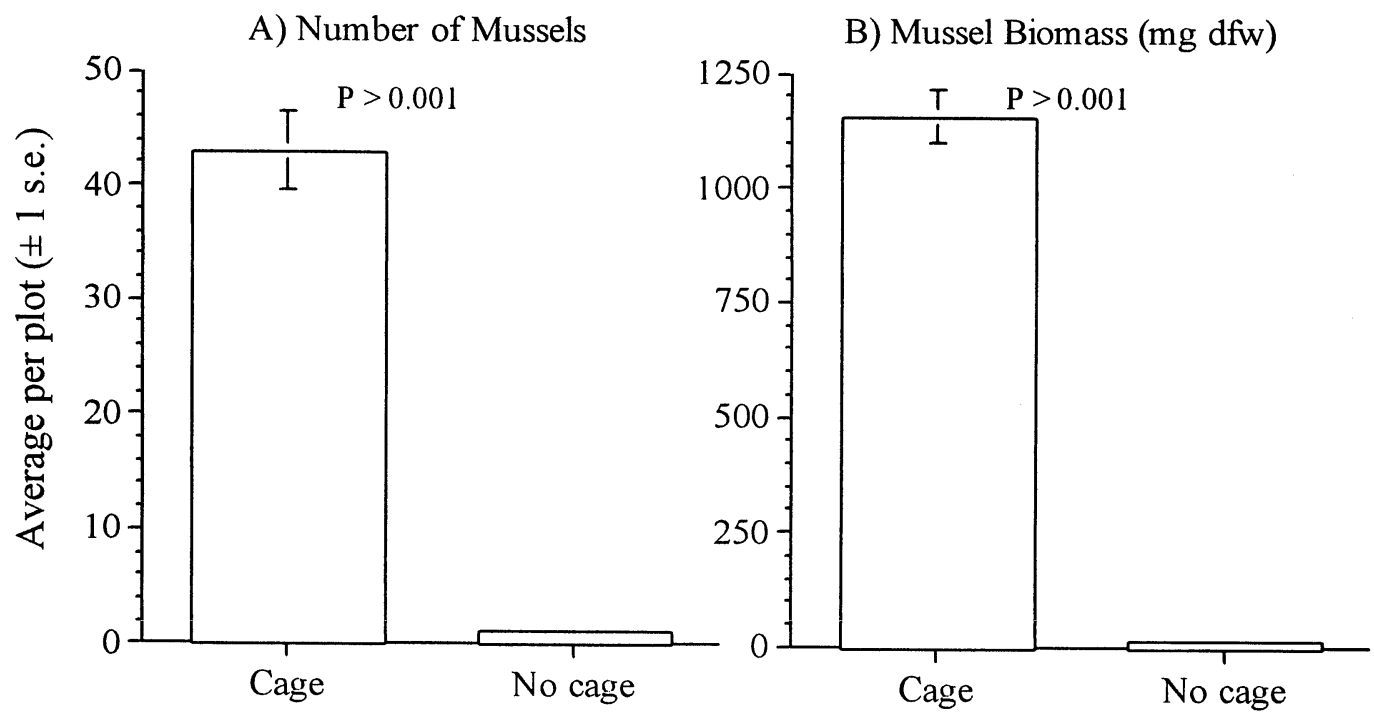

Treatment

FIgURE 1. Average $(A)$ densities and $(B)$ biomass in dry flesh weight (dfw) of Musculista senhousia in plots $\left(0.4 \mathrm{~m}^{2}\right)$ with and without sideless mesh cages. $P$ values are from paired $t$-tests.

probably willets and godwits. These birds were observed feeding at the uncaged mats, and bird footprints were typically found around these plots. Because of the nature of the sideless cages, large fish predators that feed in the intertidal, such as rays, also were excluded from the treatment plots. But it is not possible to absolutely distinguish between bird and fish predation. However, stingray feeding pits were not observed in the uncaged control plots.

\section{DISCUSSION}

In Mission Bay, three fish species, the yellowfin croaker, spotfin croaker, and sargo, and two bird species, the willet and marbled godwit, were identified as being able to utilize M. senhousia as a food source. The three fish species are common in Mission Bay and other coastal habitats and are important in local sport fisheries. The birds are primarily migratory species, although some individuals are year-round residents (Unitt 1984). These birds are both among the larger sandpipers
(Scolopacidae) commonly found on local tidal flats.

Despite the potential protection offered by the creation of the byssal cocoon, a variety of other species, including carnivorous gastropods, crustaceans, echinoderms, fish, and diving ducks are also known to eat the abundant and thin-shelled $M$. senbousia (Table 2). In the most detailed studies of the effects of a native predator on this invasive mussel, Reusch (1998) found that the muricid gastropod Pteropurpura festiva (Hinds, 1844) consumed large numbers of mussels by drilling into the thin shell. The presence or absence of the byssal cocoons had no effect on mussel mortality. Decapod crustaceans such as crabs and lobsters also are mussel predators, and these taxa tend to crush the shell and selectively remove the mussel flesh (Crooks 1992, Reusch 1998). Shorebirds such as willets and godwits manipulate the mussel to dislodge as much mat material as possible, although it appears that some mats and sediment are consumed along with the mussel. For the benthic-feeding fishes in this study, the large 
TABLE 2

Reported Predators of Musculista senbousia

\begin{tabular}{|c|c|c|c|}
\hline Species & Common Name & Location & Reference \\
\hline \multicolumn{4}{|l|}{ Crustaceans } \\
\hline Hemigrapsus oregonensis ${ }^{a}$ & Shore crab & San Diego, California & Crooks (1992) \\
\hline Panulirus interruptus & Spiny lobster & San Diego, California & Reusch (1998) \\
\hline \multicolumn{4}{|l|}{ Mollusks } \\
\hline Conus californicus & California cone & San Diego, California & Reusch (1998) \\
\hline Cymatium partbenopeum ${ }^{a}$ & Gastropod & New Zealand & Willan (1987) \\
\hline Pteropurpura festiva & Festive murex & San Diego, California & Reusch (1998) \\
\hline \multicolumn{4}{|l|}{ Echinoderms } \\
\hline Asterias amurensis & Sea star & Japan & Kikuchi and Perés (1977) \\
\hline \multicolumn{4}{|l|}{ Fish } \\
\hline Anisotremus davidsonii & Sargo & San Diego, California & This study \\
\hline Cynoglossus semilaevis & Tongue sole & China & Dou (1993) \\
\hline Hypomesus olidus & Pond smelt & Japan & Yamamoto (1977) \\
\hline Roncador stearnsii & Spotfin croaker & San Diego, California & This study \\
\hline Sparus auratus & Porgy & Suez Canal & Barash and Danin $(1971,1972)$ \\
\hline Umbrina roncador & Yellowfin croaker & San Diego, California & This study \\
\hline \multicolumn{4}{|l|}{ Birds } \\
\hline Aythya affinis & Lesser scaup & San Francisco, California & Carlton et al. (1990) \\
\hline Aythya ferina & Pochhard & Japan & Yamamuro et al. (1998) \\
\hline Aythya fuligula & Tufted duck & Japan & Yamamuro et al. (1998) \\
\hline Aythya marila & Greater scaup & $\begin{array}{l}\text { San Francisco, California; } \\
\text { Japan }\end{array}$ & $\begin{array}{l}\text { Carlton et al. (1990); } \\
\text { Yamamuro et al. (1998) }\end{array}$ \\
\hline Catoptrophorus semipalmatus & Willet & San Diego, California & This study \\
\hline Limosa fedoa & Marbled godwit & San Diego, California & This study \\
\hline Melanitta perspicillata & Surf scoter & San Francisco, California & Carlton et al. (1990) \\
\hline
\end{tabular}

${ }^{a}$ Laboratory setting.

quantity of mud in the gut suggests that these species swallow the mussels, cocoons, and associated sediments. Diving ducks also are likely to consume sediments along with the mussel.

Although it is clear that a variety of species can eat the mussel, there have been fewer studies that quantify the effects of predators on M. senhousia populations. For marine benthic systems in general, discrepancies have been found regarding the role of predators in regulating populations of smaller invertebrates. Some studies have found that predators can reduce infaunal densities, and others have found no effect (e.g., Quammen 1984, Hall et al. 1990, Thrush et al. 1994). Although some of these differences may result from experimental design considerations (such as cage effects) and lack of power, it is clear that the ability of predators to significantly affect benthic populations displays considerable spatiotemporal variability
(Thrush et al. 1994). However, M. senbousia does appear to be limited by at least some of its predators. In an experiment in a subtidal San Diego Bay eelgrass bed, the snail $P$. festiva decreased transplanted mussel populations by up to $65 \%$ within a 2 -week period, and a 4-month study revealed a $50 \%$ decrease in mussel populations within predator-exclusion plots compared with control plots (Reusch 1998). Decreases seen in transplanted intertidal mussel populations in Mission Bay were even more extreme (Figure 1).

Evidence of potential predator effects also can be extrapolated from gut content, feeding rate, and energetic studies. In a Japanese lagoon, Lake Nakaumi $\left(\right.$ area $=86.8 \mathrm{~km}^{2}$ ), diving ducks (Aytbya spp.) are important $M$. senhousia predators, and over $90 \%$ of these birds had mussel shells in the gut. It was calculated that these birds eat over $3400 \mathrm{~kg}$ of mussels a day and a total of 35 billion mussels during the wintering stay between October 
and March (Yamamuro et al. 1998). On the Mission Bay tidal flat during winter, extrapolating observed feeding rates of individual willets and godwits to the average population sizes of these birds gave a total consumption rate of approximately 9,000 mussels per hour of feeding. Such predation may in part account for observed seasonal cycles in intertidal mussel populations, with high abundances in the summer and fall and decreasing abundances in the winter and spring (Crooks 1998). Although shorebird populations are present in San Diego yearround, densities increase in the late summer and fall with the arrival of migrant birds (Unitt 1984). Sustained predation pressure over the fall and winter months may account for the large decreases in mussel densities and represent an important form of ecological resistance to intertidal mussel populations. However, this pattern is potentially confounded by the fact that the mussel is shortlived and mortality would be expected to be high even in the absence of predators. Further long-term studies are thus necessary to help clarify the role of these predators in controlling $M$. senhousia populations.

Humans also must be included among the organisms impacting populations of $M$. senbousia. The earliest records of the mussel indicate its use as a human food source in China (Benson 1855). In addition, M. senbousia is gathered as food for domestic or cultured organisms in Asian countries, including Japan, Thailand, and India. In Thailand, $M$. senbousia is used to feed ducks, chickens, fish, and shrimp (Saraya 1982, Amornjaruchit 1988, Chalermwat et al. 1988, Lutz et al. 1991). For example, in 1982, 33 tons of the mussel were collected, primarily for duck food (Lutz et al. 1991). The mussel is reportedly gathered when it is $5 \mathrm{~mm}$ long and sown on plots close to the shore. Two or three months later (at approximately $20 \mathrm{~mm}$ length), the mussels are collected and shipped to local markets. Large mussels also may be harvested from natural populations. In Japan, the mussel has also been used as bait for fishing (Kawaguti and Ikemoto 1962) and is raked from intertidal plots used for Japanese littleneck clam, Ruditapes philippinarum
(Adams \& Reeve, 1850) (Veneridae), fisheries because of its ability to smother and kill this larger bivalve (pers. obs.). No commercial or recreational uses of $M$. senbousia have been reported within invaded regions, although harvesting for feed or bait would represent a possible means of controlling the invasive mussel. However, potential benefits of mussel removal must be balanced against negative effects often associated with benthic harvesting.

\section{ACKNOWLEDGMENTS}

I thank Sarah Maresch for her work with the bird observations, and Michael Shane, Emma Crooks, Hugh Khim, David Seay, Nicole Dederick, Drew Talley, and Michael Zolkewitz for their help in the laboratory and field. I also thank Deborah Dexter, Lisa Levin, and Greg Ruiz for their continued guidance.

\section{Literature Cited}

Amornjaruchit, S. 1988. Economically important molluscan shellfish of Thailand. Pages 1-18 in E. C. McCoy and T. Chongpeepien, eds. Bivalve mollusc culture research in Thailand. International Center for Living Aquatic Resources Management Technical Reports, Bangkok, Thailand.

Barash, A., and Z. Danin. 1971. Mollusca from the stomach of Sparus auratus fished in the lagoon of Bardawil. Argamon, J. Isr. Malacol. Soc. 2:97-104.

. 1972. The Indo-Pacific species of Mollusca in the Mediterranean and notes on a collection from the Suez Canal. Isr. J. Zool. 21:301-374.

Benson, W. H. 1855. Chusan shells. J. Asiat. Soc. Bengal 24 (2): 119-140.

Carlton, J. T. 1979. History, biogeography, and ecology of the introduced marine and estuarine invertebrates of the Pacific coast of North America. Ph.D. diss., University of California, Davis.

Carlton, J. T., J. K. Thompson, L. E. Schemel, and F. H. Nichols. 1990. Remarkable invasion of San Francisco Bay (California, USA) by the Asian clam Potamocorbula 
amurensis. I. Introduction and dispersal. Mar. Ecol. Prog. Ser. 66:81-94.

Chalermwat, K., R. A. Lutz, and P. Menasveta. 1988. Mussel culture in Thailand: A synopsis. J. Shellfish Res. 7 (3): 567.

Creese, R., S. Hooker, S. DeLuca, and W. Wharton. 1997. Ecology and environmental impact of Musculista senbousia (Mollusca: Bivalvia: Mytilidae) in Tamaki Estuary, Auckland, New Zealand. N. Z. J. Mar. Freshwater Res. 31:225-236.

Crooks, J. A. 1992. The ecology of the introduced bivalve Musculista senhousia in Mission Bay, San Diego. M.S. thesis, San Diego State University, San Diego, California.

. 1996. The population ecology of an exotic mussel, Musculista senhousia, in a southern California bay. Estuaries 19 (1): 42-50.

- 1998. Habitat alteration and community-level effects of an exotic mussel, Musculista senbousia. Mar. Ecol. Prog. Ser. 162:137-152.

. 2001. Assessing invader roles within changing ecosystems: Historical and experimental perspectives on an exotic mussel in an urbanized lagoon. Biol. Invasions: 23-36.

Crooks, J. A., and H. S. Khim. 1999. Architectural vs. biological effects of a habitataltering, exotic mussel, Musculista senhousia. J. Exp. Mar. Biol. Ecol. 240:53-75.

Crooks, J. A., and M. E. Soulé. 1999. Lag times in population explosions of invasive species: Causes and implications. Pages 103-125 in O. T. Sandlund, P. J. Schei, and A. Viken, eds. Invasive species and biodiversity management. Kluwer Academic Publishers, The Netherlands.

Dexter, D. M., and J. A. Crooks. 2000. Subtidal benthic communities and the invasion of an exotic mussel in an urbanized southern California bay: A long-term history. Bull. South. Calif. Acad. Sci. 99:128-146.

Dou, S. 1993. Food habits and seasonal variation of stomach contents of tongue sole Cynoglossus semilaevis (Gunther) in the Bohai Sea. Chin. J. Oceanol. Limnol. 11:8996.

Elton, C. S. 1958. The ecology of invasions by animals and plants. John Wiley and Sons, New York.

Hall, S. J., D. Raffaelli, and W. R. Turner. 1990. Predator-caging experiments in marine systems: A reexamination of their value. Am. Nat. 136:657-672.

Hoenselaar, H. J., and J. Hoenselaar. 1989. Musculista senbousia (Benson in Cantor, 1842 ) in the western Mediterranean (Bivalvia, Mytilidae). Basteria 53:73-76.

Kawaguti, S., and N. Ikemoto. 1962. Electron microscopy on the mantle of a bivalve, Musculus senbousia during regeneration of the shell. Biol. J. Okayama Univ. 8:31-42.

Kikuchi, T., and J. M. Péres. 1977. Consumer ecology of seagrass beds. Pages 147-193 in C. P. McRoy and C. Helfferich, eds. Seagrass ecosystems: A scientific perspective. Marcel Dekker, New York.

Lutz, R. A., K. Chalermwat, A. J. Figueras, R. G. Gustafson, and C. Newell. 1991. Mussel aquaculture in marine and estuarine environments throughout the world. Pages 57-97 in W. Menzel, ed. Estuarine and marine bivalve mollusc culture. CRC Press, Boca Raton, Florida.

Mooney, H. A., and R. J. Hobbs. 2000. Invasive species in a changing world. Island Press, Washington, D.C.

Morton, B. 1974. Some aspects of the biology, population dynamics, and functional morphology of Musculista senhousia Benson (Bivalvia, Mytilidae). Pac. Sci. 28:19-33.

Parker, I. M., D. Simberloff, W. M. Lonsdale, K. Goodell, M. Wonham, P. M. Kareiva, M. H. Williamson, B. Von Holle, P. B. Moyle, J. E. Byers, and L. Goldwasser. 1999. Impact: Toward a framework for understanding the ecological effects of invaders. Biol. Invasions 1:3-19.

Quammen, M. L. 1984. Predation by shorebirds, fish and crabs on invertebrates in intertidal mudflats: An experimental test. Ecology 65:529-537.

Reusch, T. B. H. 1998. Native predators contribute to invasion resistance to the non-indigenous bivalve Musculista senbousia in southern California, USA. Mar. Ecol. Prog. Ser. 170:159-168.

Reusch, T. B. H., and S. L. Williams. 1998. Variable responses of native eelgrass Zos- 
tera marina to a non-indigenous bivalve Musculista senhousia. Oecologia (Berl.) 113:428-441.

Ruiz, G. M., P. Fofonoff, A. H. Hines, and E. D. Grosholz. 1999. Nonindigenous species as stressors in estuarine and marine communities: Assessing impacts and interactions. Limnol. Oceanogr. 44:950-972.

Saraya, A. 1982. Thailand. Pages 73-78 in F. B. Davy and M. Graham, eds. Bivalve culture in Asia and the Pacific. International Development Research Center, Ottawa, Canada.

Tanaka, M., and T. Kikuchi. 1978. Ecological studies on benthic macrofauna in Tomoe Cove, Amakusa II. Production of Musculista senhousia (Bivalvia, Mytilidae). Publ. Amakusa Mar. Biol. Lab. Kyushu Univ. 4:215-233.

Thrush, S. F., R. D. Pridmore, J. E. Hewiit, and V. J. Cummings. 1994. The importance of predators on a sandflat: Interplay between seasonal changes in prey densities and predator effects. Mar. Ecol. Prog. Ser. 107:211-222.

Unitt, P. 1984. The birds of San Diego County. San Diego Soc. Nat. Hist. Mem. 13.

Vitousek, P. M., C. M. D'Antonio, L. L. Loope, M. Rejmánek, and R. Westbrooks. 1997. Introduced species: A significant component of human-caused global change. N. Z. J. Ecol. 21:1-16.

Willan, R. C. 1987. The mussel Musculista senbousia in Australasia: Another aggressive alien highlights the need for quarantine at ports. Bull. Mar. Sci. 41:475-489.

Yamamoto, G. 1977. Successional processes observed in the freshening brackish lakes of Shimokita Peninsula. J. Faculty Mar. Sci. Technol. Tokai Univ. 10:119-128.

Yamamuro, M., N. Oka, and J. Hiratsuka. 1998. Predation by diving ducks on the biofouling mussel Musculista senbousia in a eutrophic estuarine lagoon. Mar. Ecol. Prog. Ser. 174:101-106. 